Emerging Contaminants and Associated Treatment Technologies

Biljana Balabanova

Trajce Stafilov Editors

Contaminant

Levels and

Ecological Effects

Understanding and Predicting with

Chemometric Methods

Springer 


\section{Emerging Contaminants and Associated Treatment Technologies}

\section{Series Editors}

Muhammad Zaffar Hashmi, Department of Chemistry, COMSATS University Islamabad, Pakistan

Vladimir Strezov, Department of Environmental Sciences, Macquarie University Sydney, NSW, Australia 
Emerging Contaminants and Associated Treatment Technologies focuses on contaminant matrices (air, land, water, soil, sediment), the nature of pollutants (emerging, well-known, persistent, e-waste, nanomaterials, etc.), health effects (e.g., toxicology, occupational health, infectious diseases, cancer), treatment technologies (bioremediation, sustainable waste management, low cost technologies), and issues related to economic development and policy. The book series includes current, comprehensive texts on critical national and regional environmental issues of emerging contaminants useful to scientists in academia, industry, planners, policy makers and governments from diverse disciplines. The knowledge captured in this series will assist in understanding, maintaining and improving the biosphere in which we live. The scope of the series includes monographs, professional books and graduate textbooks, edited volumes and books devoted to supporting education on environmental pollution at the graduate and post-graduate levels.

More information about this series at http://www.springer.com/series/16185 
Biljana Balabanova - Trajče Stafilov

Editors

\section{Contaminant Levels and Ecological Effects}

Understanding and Predicting with Chemometric Methods

黛 Springer 


\author{
Editors \\ Biljana Balabanova \\ Faculty of Agriculture \\ Goce Delčev University \\ Štip, North Macedonia
}

\author{
Trajče Stafilov \\ Institute of Chemistry, Faculty of Natural \\ Sciences and Mathematics \\ Saints Cyril and Methodius University \\ Skopje, North Macedonia
}

ISSN 2524-6402

ISSN 2524-6410 (electronic)

Emerging Contaminants and Associated Treatment Technologies

ISBN 978-3-030-66134-2

ISBN 978-3-030-66135-9 (eBook)

https://doi.org/10.1007/978-3-030-66135-9

(C) The Editor(s) (if applicable) and The Author(s), under exclusive license to Springer Nature Switzerland AG 2021

This work is subject to copyright. All rights are solely and exclusively licensed by the Publisher, whether the whole or part of the material is concerned, specifically the rights of translation, reprinting, reuse of illustrations, recitation, broadcasting, reproduction on microfilms or in any other physical way, and transmission or information storage and retrieval, electronic adaptation, computer software, or by similar or dissimilar methodology now known or hereafter developed.

The use of general descriptive names, registered names, trademarks, service marks, etc. in this publication does not imply, even in the absence of a specific statement, that such names are exempt from the relevant protective laws and regulations and therefore free for general use.

The publisher, the authors, and the editors are safe to assume that the advice and information in this book are believed to be true and accurate at the date of publication. Neither the publisher nor the authors or the editors give a warranty, expressed or implied, with respect to the material contained herein or for any errors or omissions that may have been made. The publisher remains neutral with regard to jurisdictional claims in published maps and institutional affiliations.

This Springer imprint is published by the registered company Springer Nature Switzerland AG The registered company address is: Gewerbestrasse 11, 6330 Cham, Switzerland 


\title{
Chapter 10 \\ Chemometric Determination of Macro- and Microelements in Barley Genotypes with Different Origin Grown in the Republic of North Macedonia
}

\author{
Natalija Markova Ruzdik, Verica Ilieva, Ljupcho Mihajlov, Sonja Ivanovska, \\ Sasa Mitrev, Darina Vulcheva, Dragomir Vulchev, Biljana Kovacevik, \\ and Mite Ilievski
}

\begin{abstract}
The main aim of this research was to determine the content of macro- and microelements in barley genotypes, with different origin and spike morphology grown under agroecological conditions in the Republic of North Macedonia. The field experiments were conducted during 2012/2013 and 2013/2014 on the research fields of the Faculty of Agriculture, "Goce Delchev" University, in Ovče Pole. The trials were arranged as randomized complete block design with three replications for each genotype. 30 winter barley genotypes with different origin were used as an experimental material. Five of them are domestic (Hit, Izvor, Egej, Line 1, and Line 2), two varieties are from Croatia (Zlatko and Rex), five genotypes have Serbian origin (NS 525, NS 565, NS 589, Somborac, and Javor), four genotypes are from Hungary (Kompolti korai, Petra, GK Stramm, and GK Judy), two genotypes have Romanian origin (Liliana and Univers), and the remaining are from Bulgaria (Obzor, Perun, Emon, Lardeya, Orfej, Imeon, Zagorec, Asparuh, Kuber, Sajra, Devinija and Odisej). From all tested barley varieties, six cultivars have six-row spike morphol-
\end{abstract}

N. Markova Ruzdik $(\bowtie) \cdot$ V. Ilieva $\cdot$ L. Mihajlov $\cdot$ M. Ilievski

Department of Plant Production, Faculty of Agriculture, Goce Delčev University,

Štip, Republic of North Macedonia

e-mail: natalija.markova@ugd.edu.mk

S. Ivanovska

Department of Genetics and Plant Breeding, Faculty of Agricultural Sciences and Food, "Ss

Cyril and Methodius" University, Skopje, Republic of North Macedonia

S. Mitrev · B. Kovacevik

Department of Plant and Environmental Protection, Faculty of Agriculture, Goce Delčev

University, Štip, Republic of North Macedonia

D. Vulcheva · D. Vulchev

Agricultural Academy, Karnobat, Republic of Bulgaria

(C) The Author(s), under exclusive license to Springer Nature

Switzerland AG 2021

B. Balabanova, T. Stafilov (eds.), Contaminant Levels and Ecological Effects,

Emerging Contaminants and Associated Treatment Technologies,

https://doi.org/10.1007/978-3-030-66135-9_10 